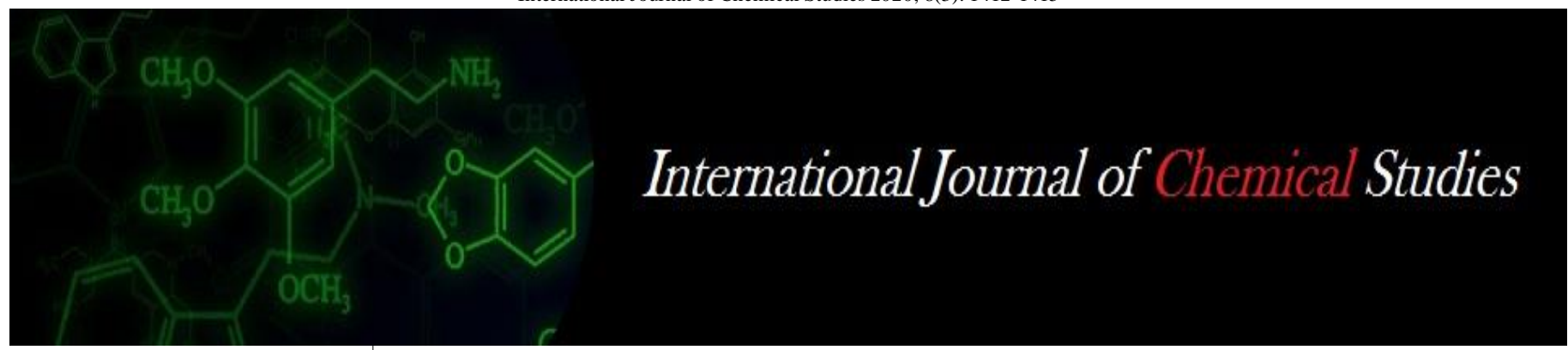

P-ISSN: 2349-8528

E-ISSN: 2321-4902

www.chemijournal.com

IJCS 2020; 8(3): 1412-1415

(C) 2020 IJCS

Received: 20-03-2020

Accepted: 22-04-2020

Debasis Sarangi

Krishi Vigyan Kendra, Ganjam-

II, Odisha University of

Agriculture and Technology,

Odisha, India

Dinabandhu Jena

Department of Soil Science and

Agricultural Chemistry, SOA

Deemed to be University,

Bhubaneswar, Odisha, India

Sushree Choudhury

Krishi Vigyan Kendra, Ganjam-

II, Odisha University of

Agriculture and Technology,

Odisha, India

Kabita Mishra

Krishi Vigyan Kendra, Ganjam-

II, Odisha University of

Agriculture and Technology,

Odisha, India
Corresponding Author: Debasis Sarangi

Krishi Vigyan Kendra, Ganjam-

II, Odisha University of

Agriculture and Technology,

Odisha, India

\section{Change in available sulphur, sulphur build up as influenced by the application of low grade rock phosphate, single super phosphate and their mixtures in a groundnut-maize cropping system on the acid Alfisols of Odisha State, India}

\author{
Debasis Sarangi, Dinabandhu Jena, Sushree Choudhury and Kabita \\ Mishra
}

DOI: https://doi.org/10.22271/chemi.2020.v8.i3s.9395

\begin{abstract}
To find out the effect of low grade Udaipur rock phosphate (URP), single super phosphate and their mixtures on soil available sulphur at different growth stages of a groundnut- maize cropping system, a field experiment was conducted in a randomized block design with three replications and eight treatments from 2013-14 to 2015. The soil has a loam texture, a pH of 5.18, low available nitrogen and medium phosphorus and potassium. In control, soil available sulphur decreased gradually from the initial value of 27.45 to $12.35 \mathrm{~kg} \mathrm{ha}^{-1}$ after four seasons. In sole URP treatments $\left(\mathrm{T}_{2}\right.$ and $\left.\mathrm{T}_{7}\right)$ the soil available sulphur in $\mathrm{T}_{2}$ and $\mathrm{T}_{7}$ after four seasons were 29.67 and $22.54 \mathrm{~kg} \mathrm{ha}^{-1}$ respectively. The highest value of soil available sulphur $38.41 \mathrm{~kg} \mathrm{ha}^{-1}$ was recorded in SSP+ lime treatment $\left(\mathrm{T}_{8}\right)$ followed by 35.71 in SSP $\left(\mathrm{T}_{3}\right)$ and 33.13 $\mathrm{kg} \mathrm{ha}^{-1}$ in URP+SSP 1:1 ( $\left.\mathrm{T}_{5}\right)$ treatments respectively.
\end{abstract}

Keywords: URP; available sulphur; sulphur build up; groundnut-maize cropping system

\section{Introduction}

Experimental site

The effects of low grade Udaipur rock phosphate (URP), single super phosphate (SSP) and their combinations on changes in soil exchangeable calcium in different growth stages was studied in a groundnut-maize cropping system during two consecutive years (2013-2014 to 2015) through a field experiment. The experiment was conducted in the Central Farm, Odisha University of Agriculture and Technology. The site is at Bhubaneswar $85^{\circ} 47^{\prime} 18^{\prime \prime} \mathrm{E}$ latitude $20^{\circ} 16^{\prime} 51^{\prime \prime} \mathrm{N}$ longitudes with an elevation of $25.9 \mathrm{~m}$ above mean sea level. It is situated at about $64 \mathrm{~km}$ away from the Bay of Bengal within the East and South- Eastern Coastal Plain agro-climatic zone of Odisha and falls under the East Coastal Plains and Hills zone of the humid tropics of India. The climate is characterized as hot, moist and sub-humid with hot summers and mild winters. Broadly, $76 \%$ of the annual rainfall is received during June September. The rainfall is monsoonal and unimodal. The south-west monsoon usually sets in around mid-June and recedes by mid-October.

\section{Experimental design and treatments}

The experiment was conducted in a randomized block design with 8 treatments and 3 replications. Treatments were : $\mathrm{T}_{1}$-Control P; $\mathrm{T}_{2}-100 \% \mathrm{P}(\mathrm{URP}) ; \mathrm{T}_{3}-100 \% \mathrm{P}(\mathrm{SSP}) ; \mathrm{T}_{4}-75 \% \mathrm{P}$ $(\mathrm{URP})+25 \% \mathrm{P}(\mathrm{SSP}) ; \mathrm{T}_{5}-50 \% \mathrm{P}(\mathrm{URP})+50 \% \mathrm{P}(\mathrm{SSP}) ; \mathrm{T}_{6}-25 \% \mathrm{P}(\mathrm{URP})+75 \% \mathrm{P}(\mathrm{SSP}) ; \mathrm{T}_{7-}$ $200 \%$ P (URP) only on $1^{\text {st }}$ crop; $\mathrm{T}_{8^{-}} 100 \%$ P (SSP) + lime@0.2 LR. Each plot was $10 \mathrm{~m}$ x10 $\mathrm{m}$. The groundnut crop cv. TAG 24 of 115 days duration was sown during rabi 2013-14 and rabi 2014-15 at a spacing of $30 \times 10 \mathrm{~cm}$. Except the control treatment $\left(\mathrm{T}_{1}\right)$, the crop received recommended doses of $\mathrm{N}, \mathrm{P}_{2} \mathrm{O}_{5}, \mathrm{~K}_{2} \mathrm{O} @ 20: 40: 40 \mathrm{~kg} \mathrm{ha}^{-1}$. Control treatment $\left(\mathrm{T}_{1}\right)$ received only $\mathrm{N}$ and $\mathrm{K}_{2} \mathrm{O}$ at 20 and $40 \mathrm{~kg} \mathrm{ha}^{-1}$ respectively. All $\mathrm{N}, \mathrm{P}, \mathrm{K}$ were applied as basal dose. Phosphorus was applied in all the treatments from $T_{2}$ to $T_{8}$ with the sources as per treatments. The hybrid maize crop cv. P-3441 of 90 days duration was sown during kharif 2014 and kharif 
2015 at a spacing of $60 \times 30 \mathrm{~cm}$. Except the control treatment $\left(\mathrm{T}_{1}\right)$, the crop received recommended doses of $\mathrm{N}, \mathrm{P}_{2} \mathrm{O}_{5}, \mathrm{~K}_{2} \mathrm{O}$ @ 100:50:50 kg ha-1 . Control treatment $\left(\mathrm{T}_{1}\right)$ received only $\mathrm{N}$ and $\mathrm{K}_{2} \mathrm{O} 100$ and $50 \mathrm{~kg} \mathrm{ha}^{-1}$. The crop received one third dose of nitrogen, full dose of $\mathrm{P}$ and half dose of $\mathrm{K}$ as basal at the time of sowing. Rest one third dose of nitrogen and half dose of potash were applied at 25 DAS. Remaining one third dose of nitrogen was applied at 50 DAS. Phosphorus was applied in all the treatments from $\mathrm{T}_{2}$ to $\mathrm{T}_{8}$ as per treatments at sowing. A composite soil sample (0 $-15 \mathrm{~cm}$ depth) was collected from the experimental site before sowing of seeds and fertilizers application.

\section{Crop management}

All the recommended agronomic practices i.e., irrigation, intercultural operations, pest control were uniformly kept in all the treatments as and when needed. The mean temperatures during groundnut crop growing seasons were $26.5^{\circ} \mathrm{C}$ and $28.0^{\circ} \mathrm{C}$ respectively while the relative humidity $67.6 \%$ and $67.0 \%$ respectively. The mean temperatures during hybrid maize crop growing seasons were $27.9^{\circ} \mathrm{C}$ and $28.8^{\circ} \mathrm{C}$ respectively while the relative humidity $83.7 \%$ and $82.3 \%$ respectively.

\section{Soil sampling, processing and analysis}

Soil samples $(0-15 \mathrm{~cm})$ were collected from each treatment replication wise at flowering (30 DAS), pod formation (60 DAS) and harvesting (115 DAS) stage of groundnut crop and knee-high (30 DAS), tasseling (60 DAS) and harvesting stage (90 DAS) stage of maize crop. The samples were air dried under shade, crushed with wooden hammer and passed through $2 \mathrm{~mm}$ sieve and preserved in polythene bags for analysis. Analyses were for: soil texture, bulk density, water holding capacity, $\mathrm{pH}$, electrical conductivity, lime requirement value, organic carbon, exchange acidity, exchangeable acidity, exchangeable calcium, effective cation exchange capacity, available nitrogen, available phosphorus, available potassium, available sulfur. The texture of soil samples were determined with the help of Bouyoucous Hydrometer as given by Piper (1950) ${ }^{[11]}$. The bulk density of soil (undisturbed) was determined by Core method (Black, 1965) ${ }^{[1]}$. The water holding capacity of soil samples were determined by Keen Raczkowski Box method (Piper, 1950) [11]. The $\mathrm{pH}$ was determined in 1:2.5 soil-water ratio by $\mathrm{pH}$ meter (ELICO LI 613 pH meter) as described by Jackson (1973) ${ }^{[8]}$. As suggested by Jackson (1973) ${ }^{[8]}$, the electrical conductivity of soil samples was determined in 1:2.5 soilwater suspension by conductivity meter (ELICO CM 180 Conductivity meter). Lime requirement value of soil was determined by Woodruff Buffer method (Woodruff, 1948). The organic carbon content of soil was determined by Wet digestion procedure of Walkley and Black (1934) ${ }^{[14]}$ as outlined in soil chemical analysis (Page et al., 1982) ${ }^{[10]}$. Exchange acidity, exchangeable acidity: Exchange acidity, exchangeable acidity were estimated by using the methods of Lin and Coleman (1960) ${ }^{[9]}$ as described by Page et al., (1982) [10]. Exchangeable Calcium was determined using EDTA (Versenate) complexometric titration by using Calcon indicator as outline by Hesse (1971) ${ }^{[7]}$. Effective Cation
Exchange Capacity refers to the sum of the milli equivalents of $\mathrm{Ca}, \mathrm{Mg}, \mathrm{K}, \mathrm{Na}$ plus $\mathrm{H}$ and $\mathrm{Al}$. Exchangeable $\mathrm{Ca}, \mathrm{Mg}, \mathrm{K}$ and $\mathrm{Na}$ were extracted using neutral normal ammonium acetate and determined separately. Available nitrogen in soil was determined by alkaline $\mathrm{KMnO} 4$ method (Subbiah and Asija, 1956) [13] using Kelplus nitrogen auto analyzer (Kelplus: Model classic DX). Available phosphorous in the soil was determined by Bray's 1 method (Bray and Kurtz, $1945)^{[2]}$ as out lined by Page et al., (1982) ${ }^{[10]}$. Available potassium was determined by extracting the soil with neutral normal ammonium acetate solution and estimated by flame photometer as described by Hanway and Heidal (1952) ${ }^{[6]}$. The available $\mathrm{S}$ content was determined turbidimetrically following the procedure of Chesnin and Yien (1952) ${ }^{[3]}$ as described by Page et al., (1982) ${ }^{[10]}$.

\section{Statistical analysis of data}

The data from the experiment were analysed statistically following the procedure given by Gomez and Gomez (1984) [5]. Whenever the treatmental differences were significant, critical difference were calculated at five per cent probability level and used for interpretations.

\section{Results and discussion}

The soil of the experimental site is loam in texture with $64.6 \%$ sand, $14.8 \%$ silt and $20.6 \%$ of clay. The maximum water holding capacity is $31 \%$ with bulk density (BD) $1.59 \mathrm{Mg} \mathrm{m}^{-3}$. The soil is acidic in reaction ( $\mathrm{pH}-5.18$ ), non saline (EC- 0.09 $\mathrm{dS} \mathrm{m}{ }^{-1}$ ) with exchangeable $\mathrm{Al}^{3+}$ and exchangeable $\mathrm{H}^{+}$of 0.05 and $0.06 \mathrm{c} \mathrm{mol}(\mathrm{p}+) \mathrm{kg}^{-1}$ respectively. The soil is low in available $\mathrm{N}\left(239.0 \mathrm{~kg} \mathrm{ha}^{-1}\right)$, medium in $\mathrm{P}\left(14.64 \mathrm{~kg} \mathrm{ha}^{-1}\right)$ and $\mathrm{K}\left(150.0 \mathrm{~kg} \mathrm{ha}^{-1}\right)$ and $\mathrm{S}\left(27.4 \mathrm{~kg} \mathrm{ha}^{-1}\right)$ indicating low soil fertility. The CEC is $4.2 \mathrm{c} \mathrm{mol}\left(\mathrm{p}^{+}\right) \mathrm{kg}^{-1}$ soil and base saturation of $43 \%$. The samples of URP used had $7.8 \%$ total $\mathrm{P}, 25.6 \% \mathrm{Ca}, 0.26 \% \mathrm{Mg}, 0.24 \% \mathrm{~K}$ and $1.2 \% \mathrm{~S}$ indicating a moderate reactivity of the material.

\section{Available sulphur}

Figure 1 presented the available sulphur content in soil at various stages of growth of groundnut- maize cropping system. In control treatment the available sulphur content decreased gradually from initial value of $27.45 \mathrm{~kg} \mathrm{ha}^{-1}$ to $26.63,24.83$ and $22.18 \mathrm{~kg} \mathrm{ha}^{-1}$ at flowering, pod formation and harvest stage of groundnut during rabi 2013-14.

On the other hand, when the crop received URP alone either at $100 \%\left(\mathrm{~T}_{2}\right)$ or $200 \% \mathrm{P}\left(\mathrm{T}_{7}\right)$, it increased from initial value, attained the peak (28.75-29.17 $\left.\mathrm{kg} \mathrm{ha}^{-1}\right)$ at pod formation stage and then declined at harvest. At harvest the values were lower than the initial value. But in other treatments, the peak was attained at flowering stage and thereafter decreased gradually at pod formation and harvest stage. Among the treatments, $\mathrm{SSP}+$ lime treatment recorded significantly higher available sulphur followed by SSP at all growth stages indicating that lime application induces sulphur availability.

Further the data showed that similar trend of available sulphur was recorded at different growth stages of second (maize), third (groundnut) and fourth (maize) crop. The value of available sulphur was also increased over seasons in all treatments with few exceptions. 


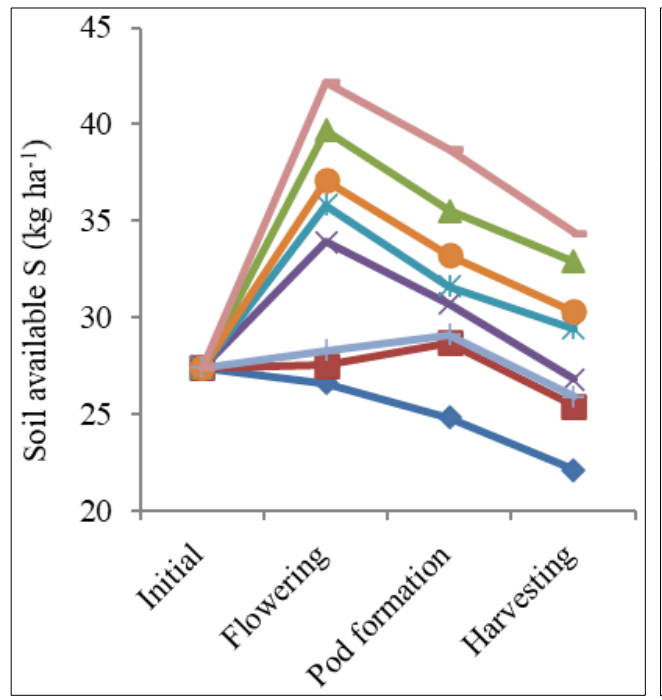

a. Groundnut (Rabi 2013-14)

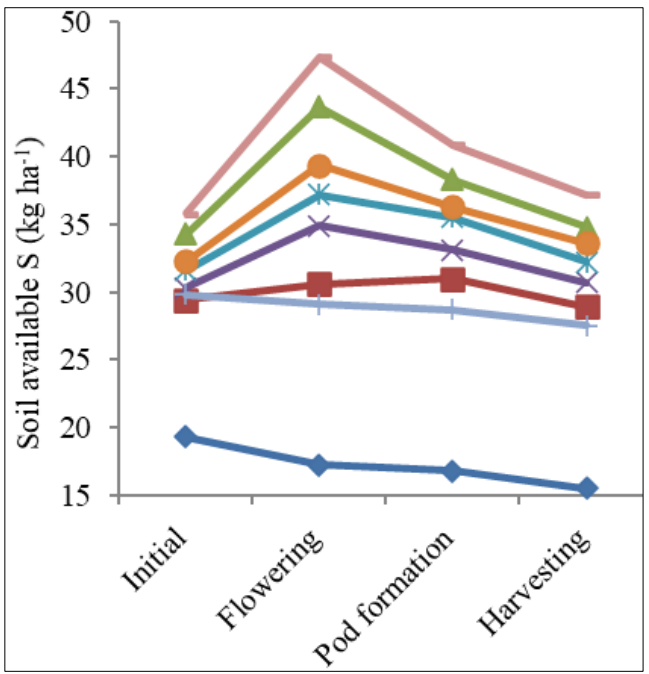

c. Groundnut (Rabi 2014-15)

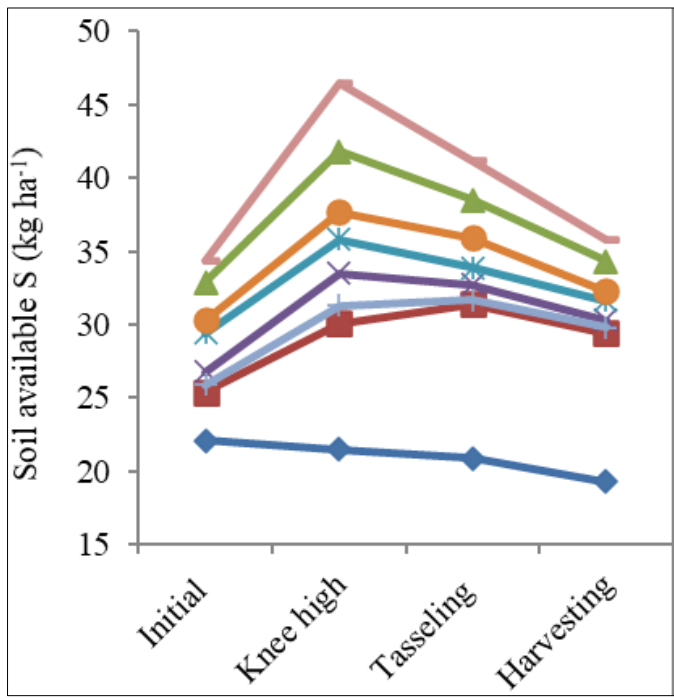

b. Maize (Kharif 2014)

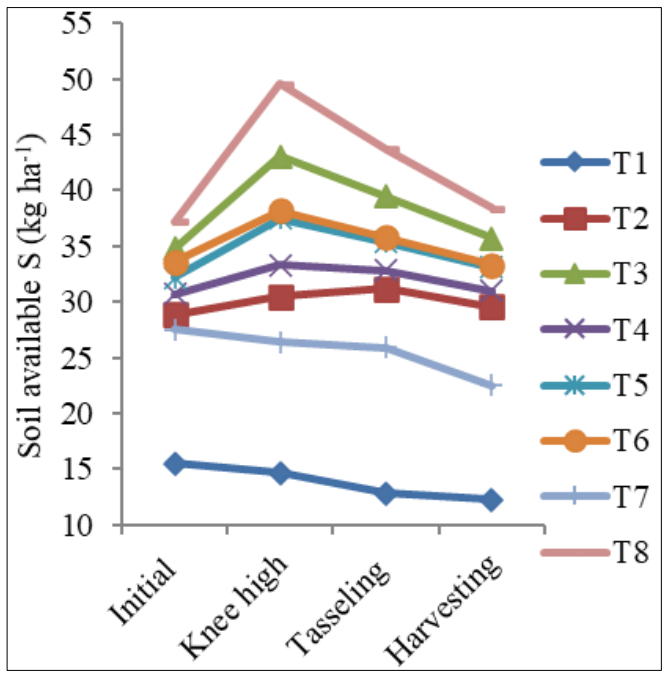

d. Maize (Kharif 2015)

Fig 1: (a, b, c, d) Effects of treatments on soil available $S\left(\mathrm{~kg} \mathrm{ha}^{-1}\right)$ at different growth stages of groundnut and maize

\section{Available sulphur build up in soil}

Table 1 and figure 2 presented the value of available sulphur build up in soil after harvest of four crops. The available sulphur before start of the experiment was $27.5 \mathrm{~kg} \mathrm{ha}^{-1}$ indicating a medium soil sulphur status. During four cropping seasons (the crop) received $180 \mathrm{~kg} \mathrm{P}_{2} \mathrm{O}_{5} \mathrm{ha}^{-1}$ through $1125 \mathrm{~kg}$ $\mathrm{SSP}$ in $\mathrm{T}_{3}$ which add $135 \mathrm{~kg} \mathrm{~S} \mathrm{ha}^{-1}$. In other words, $\mathrm{T}_{3}$ and $\mathrm{T}_{8}$ treatment received $135 \mathrm{~kg} \mathrm{~S}^{-1}$ over four seasons. The data presented in Table 1 showed that after the harvest of four crops, the available sulphur in control decreased from 27.45 $\mathrm{kg} \mathrm{ha}^{-1}$ to $12.3 \mathrm{~kg} \mathrm{ha}^{-1}$ indicating a negative build up of 15.15 $\mathrm{kg} \mathrm{S} \mathrm{ha}^{-1}(-55.2 \%)$ was due to crop removal. Application of
URP $\left(\mathrm{T}_{2}\right)$ alone recorded $7.8 \%$ available sulphur build up as compared to initial value. The build-up in available sulphur further increased by 13 to $21 \%$ when the crop received URP+SSP mixture in $3: 1$ or $1: 1$ or $1: 3$ ratio. Application of whole $\mathrm{P}$ through SSP $\left(\mathrm{T}_{3}\right)$ further increased the $\mathrm{S}$ build up to $30 \%$. Application of SSP, URP+SSP resulted in significantly higher soil available sulphur over sole URP treatments was due to addition of $\mathrm{S}$ through SSP. Application of lime with SSP recorded the maximum build up which is about $40 \%$ higher over the initial value indicating a rise in $\mathrm{pH}$ through liming induces the sulphur availability in soil. Shinde et al. $(1978 b)^{[12]}$, Das et al. $(1982)^{[4]}$ reported similar results.

Table 1: Available $S$ build up $\left(\mathrm{kg} \mathrm{ha}^{-1}\right)$ in soil after harvest of fourth crop in groundnut-maize cropping system

\begin{tabular}{|c|c|c|c|c|}
\hline $\begin{array}{l}\text { S. } \\
\text { No. }\end{array}$ & Treatments & $\begin{array}{l}\text { Initial soil available } \\
\text { sulphur }\left(\mathrm{kg} \mathrm{ha}^{-1}\right)\end{array}$ & $\begin{array}{c}\text { Soil available sulphur after harvest of } 4^{\text {th }} \\
\text { crop }\left(\mathrm{kg} \mathrm{ha}^{-1}\right)\end{array}$ & $\begin{array}{c}\text { Available } S \text { build up } \\
\left(\mathrm{kg} \mathrm{ha}^{-1}\right)\end{array}$ \\
\hline $\mathrm{T} 1$ & Control & 27.45 & 12.35 & $-15.1(-55.01)$ \\
\hline $\mathrm{T} 2$ & $100 \% \mathrm{P}(\mathrm{URP})$ & 27.45 & 29.67 & $2.22(8.09)$ \\
\hline $\mathrm{T} 3$ & $100 \% \mathrm{P}(\mathrm{SSP})$ & 27.45 & 35.71 & $8.26(30.09)$ \\
\hline $\mathrm{T} 4$ & $75 \% \mathrm{P}(\mathrm{URP})+25 \% \mathrm{P}(\mathrm{SSP})$ & 27.45 & 31.18 & $3.73(13.59)$ \\
\hline T5 & $50 \% \mathrm{P}(\mathrm{URP})+50 \% \mathrm{P}(\mathrm{SSP})$ & 27.45 & 33.13 & $5.68(20.69)$ \\
\hline T6 & $25 \% \mathrm{P}(\mathrm{URP})+75 \% \mathrm{P}(\mathrm{SSP})$ & 27.45 & 33.36 & $5.91(21.53)$ \\
\hline $\mathrm{T} 7$ & $200 \%$ P(URP) only on $1^{\text {st }}$ crop & 27.45 & 22.54 & $-4.91(-17.89)$ \\
\hline $\mathrm{T} 8$ & 100\%P(SSP)+Lime@0.2 LR & 27.45 & 38.41 & $10.96(39.93)$ \\
\hline
\end{tabular}

*Figures in parentheses indicate percentage of $\mathrm{S}$ build up 


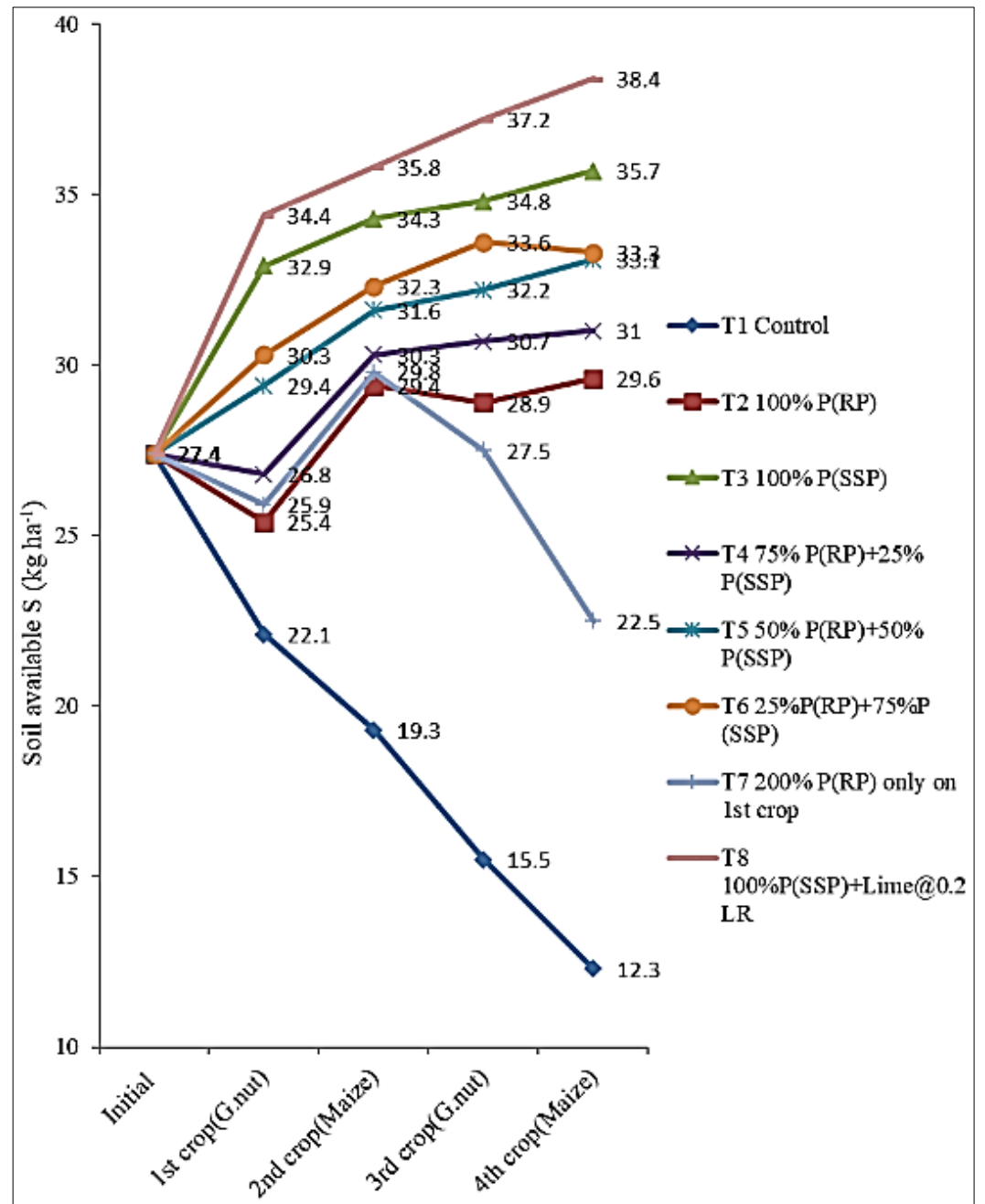

Fig 2: Effects of treatments on soil available $\mathrm{S}\left(\mathrm{kg} \mathrm{ha}^{-1}\right)$ at harvest of crops over four seasons

\section{Conclusion}

The build-up in available sulphur increased by $21 \%$ over the initial value when the crop received URP and SSP in 1:1 ratio. Application of $\mathrm{P}$ through SSP $\left(\mathrm{T}_{3}\right)$ increased the sulphur build up by $30 \%$. Application of lime with SSP resulted highest value of available sulphur build up which is about $40 \%$ higher over the initial value.

\section{References}

1. Black CA. American Society of Agronomy, Madison, Wisconsin, USA. 1965; Methods of Soil Analysis. Part I,

2. Bray RH and Kurtz LT. Determination of total organic and available forms of phosphorus in soils, Soil Science. 1945; 59:39-45.

3. Chesnin $\mathrm{L}$, Yien $\mathrm{CH}$. Turbidimetric determination of available sulphur, Soil Science Society of America Proceeding. 1952; 15:149-151.

4. Das SP, Roy M, Mandal B, Chakraborty T. Use of Purulia rock phosphate in acid soil of West Bengal, Proceedings of the symposium on phosphate management of crops with special reference to use of rock phosphate as direct fertilizer, Sriniketan, February 22 and 23, 1982, 19-22.

5. Gomez KA, Gomez AA. Statistical Procedures for Agricultural Research with Emphasis on Rice, Los Banos, the Philippines: International Rice Research Institute, 1984

6. Hanway JJ, Heidel H. Soil Analysis methods as used in Lowa State College, Soil Testing Laboratory, Lowa State College Bulletin. 1952; 57:1-131.
7. Hesse PR. A text book of soil chemical analysis, John Murray, London, 1971.

8. Jackson ML. Soil chemical Analysis, Prentice Hall of India, Pvt. Ltd., New Delhi, 1973.

9. Lin C, Coleman NT. The measurement of exchangeable aluminium in soils and Clays, Soil Science Society of America Proceedings. 1960; 24:444-446.

10. Page AL, Miller RH, Kenny DR. Method of soil analysis (Part-2). Chemical and microbial properties. Second Edition, Number 9 in the series, American Society of Agronomy and Soil Science of America. Time Publisher, Kisconsi, USA, 1982.

11. Piper CS. Soil and Plant Analysis, University Adelaide, Australia, 1950.

12. Shinde BN, Sarangamath PA, Patnaik S. Efficiency of $\mathrm{HCl}^{-}$and $\mathrm{H}_{2} \mathrm{SO}_{4}^{-}$acidulated rock phosphates for rice (Oryza sativa L.) on acid soils, Plant and Soil. 1978b; 50:575-84.

13. Subbiah BV. Asija GL. A rapid procedure for determination of available nitrogen in rice soils, Current Science. 1956; 31:196.

14. Walkley AJ, Black IA. Estimation of organic carbon by chromic acid titration method, Soil Science. 1934; 37:2938.

15. Woodruff CM. Testing soils for lime requirement by means of a buffered solution and the glass electrode, Soil Science. 1948; 66:53-63. 